\title{
Modeling the effect of age at calving $\times$ breed group of dam's interaction on weaning weight of Charolais-Zebu crossbred calves ${ }^{1}$
}

\section{Fábio Luiz Buranelo Toral ${ }^{2}$, Roberto Augusto de Almeida Torres Júnior ${ }^{3}$, Paulo Sávio Lopes ${ }^{4}$, Luiz Otávio Campos da Silva ${ }^{3}$, João Cruz Reis Filho ${ }^{5}$}

${ }^{1}$ Apoio financeiro da FAPEMIG.

2 Universidade Federal de Minas Gerais.

${ }^{3}$ Embrapa Gado de Corte.

${ }^{4}$ Universidade Federal de Viçosa. Bolsista do CNPq.

${ }^{5}$ Ministério da Agricultura, Pecuária e Abastecimento.

ABSTRACT - The objective of this study was to evaluate alternatives for modeling the interaction between age of dam at calving (AOD) and the dam genetic group (DGG) on the weaning weight (W225) of Charolais-Zebu (Ch-Z) crossbred calves. Data from 56,965 crossbred calves were analyzed by the least square method. Regression coefficients for age of dam at calving were estimated nested into each class of the dam genetic group (CLA model); for age of dam at calving $\times$ dam Charolais percentage (age of dam at calving $\times$ FCh) and age of dam at calving $\times$ dam heterozygosity (age of dam at calving $\times$ FH) $(\mathrm{FChFH}$ model); for age of dam at calving $\times$ dam Charolais percentage (FCh model); for age of dam at calving $\times$ FH $(\mathrm{FH}$ model); or only for age of dam at calving (NINT model). Segmented polynomials were used to model the general shape of the age of dam at calving effect and its interaction with dam genetic group. The knots were at 6.33 and 10.66 years of age of dam at calving and general linear and quadratic coefficient regression and specific quadratic coefficient regression after each knot were fitted. The regression coefficients were estimated nested within sex of the calf in all situations. According to the $\mathrm{F}$ test for sum of squared residuals differences, the inclusion of the age of dam at calving $\times \mathrm{FH}$ interaction did not improve the fit of the model and the CLA model provided the best fit. However, the estimates of the age of dam at calving and dam genetic group interaction from the CLA model for dam genetic group $\times$ sex of the calf classes with few records were not appropriate, but the estimates of the age of dam at calving and dam genetic group interaction from the FCh model for those classes were appropriate. The differences were small in the estimates of the age of dam of calving and dam genetic group interaction from the CLA or FCh models for dam genetic group $\times$ sex of the calf classes with many records.

Key Words: crossbreeding, heterozygosis, least square, multiple-breed genetic evaluation

\section{Modelagem da interação idade ao parto × composição genética da vaca e seus efeitos sobre o peso à desmama de bezerros mestiços Charolês-Zebu}

RESUMO - Este trabalho foi realizado com o objetivo de avaliar alternativas para modelar a interação entre idade ao parto e grupo genético da vaca (GGV) sobre o peso à desmama de bezerros mestiços Charolês-Zebu. Dados de peso à desmama de 56.965 bezerros Charolês-Zebu foram analisados utilizando o método de quadrados mínimos. Foram estimados coeficientes de regressão para idade da vaca ao parto (IVP) dentro de cada grupo genético da vaca (modelo CLA); para IVP $\times$ fração esperada de alelos de origem da raça Charolesa na vaca (IVP $\times$ FCh) e IVP $\times$ fração esperada dos loci da vaca com um alelo proveniente da raça Charolesa e outro proveniente de raças zebuínas (IVP $\times$ FH) (modelo FChFH); para IVP $\times$ FCh (modelo FCh); para IVP $\times$ FH (modelo FH); ou apenas para IVP (modelo SINT). A forma geral do efeito da IVP sobre o peso à desmama foi modelada por polinômios segmentados com efeitos linear e quadrático gerais e quadráticos específicos, a partir de cada nó (6,33 e 10,66 anos). Os coeficientes de regressão foram estimados dentro de cada sexo do bezerro em todas as situações. De acordo com o teste $\mathrm{F}$ para redução da soma de quadrados do resíduo, a inclusão da interação IVP $\times$ FH não melhorou significativamente os ajustes e o modelo CLA foi o que melhor se ajustou aos dados. Contudo, para classes de GGV × sexo do bezerro com reduzido número de observações, o modelo CLA proporcionou estimativas inconsistentes para o efeito da interação IVP $\times$ GGV e o modelo FCh mostrou-se adequado. Para as classes de GGV $\times$ sexo do bezerro com grande número de observações, as diferenças entre as estimativas do efeito da interação IVP $\times$ GGV obtidas pelos modelos CLA e FCh foram de pequena magnitude.

Palavras-chave: avaliação genética multirracial, cruzamento, heterozigose, quadrados mínimos 


\section{Introduction}

Differences in weaning weight in beef cattle can be attributed to genetic and environmental factors. Additive and non-additive genetic effects can be sources of significant variation on milk production of the dam (Alencar et al., 1996; Cerdótes et al., 2004), therefore they might influence calf weaning weight.

The age of dam at calving (AOD) plays an important role in the pre-weaning development of the calves. The age at calving significantly influences the milk production of the dam (Teodoro et al., 2000), consequently, significant effects are expected from this factor on the weight of the calves at weaning.

Significant interactions between age of dam at calving and the dam genetic group (DGG) have been reported for the weaning weight in populations of crossbred beef cattle (Massey \& Benishek, 1981; Elzo et al., 1987; Gregory et al., 1991; Alencar et al., 1999b). To fit the age of dam at calving effect to each dam genetic group separately is complicated because there are several genetic groups, and not considering the effect of the age of dam at calving $\mathrm{x}$ dam genetic group interaction on the genetic evaluations can damage the prediction of the genetic values.

The objective of the present study was to identify alternatives to model the interaction between the age at calving and the dam genetic group on the weaning weight of beef cattle.

\section{Material and Methods}

A total of 56,965 weaning weight data of CharolaisZebu (Ch-Z) crossbred calves, standardized to and age of 225 days (W225), was used. These calves are involved in the formation of Canchim breed and the data were supplied by the Associação Brasileira de Criadores de Canchim (ABCCAN). Data refer to the calves born between 1988 and 2005, from single births on 247 farms located in the following Brazilian regions: South (Rio Grande do Sul, Santa Catarina and Paraná), Southeast (São Paulo, Rio de Janeiro and Minas Gerais), Central-West (Mato Grosso do Sul, Mato Grosso, Goiás and Distrito Federal), Northeast (Bahia, Pernambuco, Piauí and Maranhão) and North (Tocantins and Pará). Additional information on this database can be obtained in Toral et al. (2009).

The Canchim breed is a compound breed, with approximately $5 / 8$ alleles derived from the Charolais breed and $3 / 8$ alleles derived from the Zebu breeds (5/8 Ch + $3 / 8 \mathrm{Z}$ ), and the Nellore ( $\mathrm{N}$ ) is the most representative Zebu breed. Currently, the ABCCAN records animals from four mating schemes (Table 1).

Analyses of variance were performed for W225 by the least square method, considering the following statistical model:

$W 225_{i j k l m}=\mu+C G_{j}+S G G_{k}+D G G_{l}+a_{1(l s)} A O D_{m}+a_{2(l s)} A O D_{m}^{2}$ $+a_{3(l s)} \max \left(0, A O D_{m}-6,33\right)^{2}+a_{4(s)} \max \left(0, A O D_{m}-10,66\right)^{2}+e_{i j k l m}[1]$ where: $W 225_{i j k l m}=$ the $\mathrm{W} 225$ of animal $i$, raised in the contemporary group $j$, offspring of a sire from genetic group $k$ and a dam from genetic group $l$ with age at calving $m$; $\mu$ = a general constant; $G G_{j}=$ the effect of the contemporary group $j(j=1 ; \ldots ; 4,458) ; S G G_{k}=$ the effect of the sire genetic group $k$ ( $k=\mathrm{Z}, 5 / 8 \mathrm{Ch}$ [sire $\mathrm{Ch} \mathrm{x}$ dam $1 / 4 \mathrm{Ch}$ ], Canchim [5/8 Ch x 5/8 Ch], 21/32 Ch and Ch); $D G G_{l}=$ the effect of dam genetic group $l$ ( $l=1 / 4 \mathrm{Ch}, 5 / 16 \mathrm{Ch}$ or A, 15/32 Ch or $\mathrm{T} 1,1 / 2$ Ch or T2, 9/16 Ch or V, 5/8Ch [sire Ch x dam 1/4 Ch], Canchim [5/8 Ch x 5/8 Ch] and 21/32 Ch or MA); $a_{p(s)}=$ the $p^{\text {eth }}$ regression coefficient ( $p=1,2,3$ and 4 ) for age of dam at calving nested in each $D G G_{l}$ combination and sex of the calf $s$ ( $s=$ male and female); and $e_{i j k l m}=$ the random error associated to each observation, $e_{i j k l m} \sim \operatorname{NIID}\left(0, \sigma_{e}^{2}\right)$. The general form of the AOD effect in [1] defined in years with centesimal precision, was modeled by segmented polynomials with general linear and quadratic and specific quadratic effects, starting from the knots at 6.33 and 10.66 years of age, according to the recommendation by Toral et al. (2009).

In the model represented in [1], called CLA, 64 regression coefficients were contemplated (four regression coefficients $\times$ eight DGG $\times$ two sexes). To reduce the complexity, the FChFH model was proposed and it is represented by:

$$
\begin{aligned}
& W 225_{i j k l m}=\mu+C G_{j}+S G G_{k}+D G G_{l}+a_{1(s)} A O D_{m}+a_{2(s)} A O D_{m}^{2}+a_{3(s)} \max \left(0, A O D_{m}-6.33\right)^{2} \\
& +a_{4(s)} \max \left(0, A O D_{m}-10.66\right)^{2}+b_{1(s)} A O D_{m} F C h_{l}+b_{2(s)} A O D_{m}^{2} F C h_{l} \\
& +b_{3(s)} \max \left(0, A O D_{m}-6.33\right)^{2} F C h_{l}+b_{4(s)} \max \left(0, A O D_{m}-10.66\right)^{2} F C h_{l}+c_{1(s)} A O D_{m} F H_{l} \\
& +c_{2(s)} A O D_{m}^{2} F H_{l}+c_{3(s)} \max \left(0, A O D_{m}-6.33\right)^{2} F H_{l}+c_{4(s)} \max \left(0, A O D_{m}-10.66\right)^{2} F H_{l}+e_{i j k m m}
\end{aligned}
$$

The regression coefficients $b_{p(s)}$ and $c_{p(s)}$ and the variables $F C h_{l}$ (expected allele fraction derived from the Charolais breed in dam $l$, dam of animal $i$ ) and $F H_{l}$ (expected loci fraction of dam with an allele from the Charolais breed and another from the Zebu breeds) included in the FChFH model are useful to estimate the AOD interactions with additive and non-additive genetic effects. In [2], the regression coefficients $a_{p(s)}$ served to model the AOD effect of the Zebu dams on W225 $\left(\mathrm{FCH}_{l}=\mathrm{FH}_{l}=0\right)$, the coefficients $b_{p(s)}$ served to model the differences between the effects of the AOD of Charolais and Zebu dams on W225 and the coefficients $c_{p(s)}$ were used to model the effect of the AOD $\times$ FH interaction on W225.

The FCh of each animal was obtained from the mean of the FCh of its parents, from the oldest ancestor. The FH of 
each animal (including the dams) was obtained from the expression $F H_{i}=F C h_{m_{i}} \times\left(1-F C h_{p_{i}}\right)+F C h_{p_{i}} \times\left(1-F C h_{m_{i}}\right)$, [3] where: $\mathrm{FH}_{i}=$ the expected loci fraction from animal with an allele from the Charolais breed and another from Zebu breeds; and $F C h_{m i}$ and $F C h_{p i}=$ the expected allele fraction derived from the Charolais breed in the dam and sire of $i$, respectively. The FH theoretic means, considered for the groups Z, 1/4 Ch, 5/16 Ch (A), 15/32 Ch (T1), 1/2 Ch (T2), 9/16 Ch (V), 5/8Ch (sire Ch $\times$ dam 1/4Ch), Canchim (5/8 Ch $\times 5 / 8 \mathrm{Ch}$ ), 21/32 Ch (MA) and Ch were: 0, 0.5, 0.625, $0.546875,1,0.5,0.75,0.46875,0.6875$ and 0 .

A total of 24 regression coefficients was used in the FChFH model (12 regression coefficients $\times$ two sexes). Models similar to the FChFH were also assessed but taking into consideration only the coefficients $a_{p(s)}$ and $b_{p(s)}$ (FCh model), $a_{p(s)}$ and $c_{p(s)}$ (FH model) and $a_{p(s)}$ (NINT model). In the FCh model, interaction of the AOD effect was presumed only for the FCh of the dam; in the FH model, interaction of the AOD effect with the FH of the dam was presumed and in the NINT model it was presumed that there was no effect of the AOD and dam genetic composition interaction (FCh or FH) on W225. Sixteen regression coefficients were estimated in the FCh and FH models and eight coefficients were estimated in the NINT model.

The following criteria were used to compare the models: the sum of squared residuals (SSR); the F test of the SSR reduction in subsequent models; the coefficient of determination of the model $\left(\mathrm{R}^{2}\right)$; and the efficiency of the additional degrees of freedom of the model (EDF). The EDF were obtained from the ratio between the differences in SSR in two sequential models and the differences in the degrees of freedom of their errors.

Finally, the W225 estimates ( $W$ 225) were obtained from the estimates of the least squares of the fixed effects included in the CLA, FChFH, FCh, FH and NINT models. In the present case, the estimates of the general constants of the models and the classificatory effects involved complex combinations of the solutions obtained for the intercept, sire and dam genetic groups and contemporary groups, and could not even be estimated. Thus, it was chosen to use a variable which was called the curve shape (CS) and expressed in kilograms, consisting of the difference between $(W \hat{2} 25)$

Table 1 - Mating schemes to obtain Canchim cattle

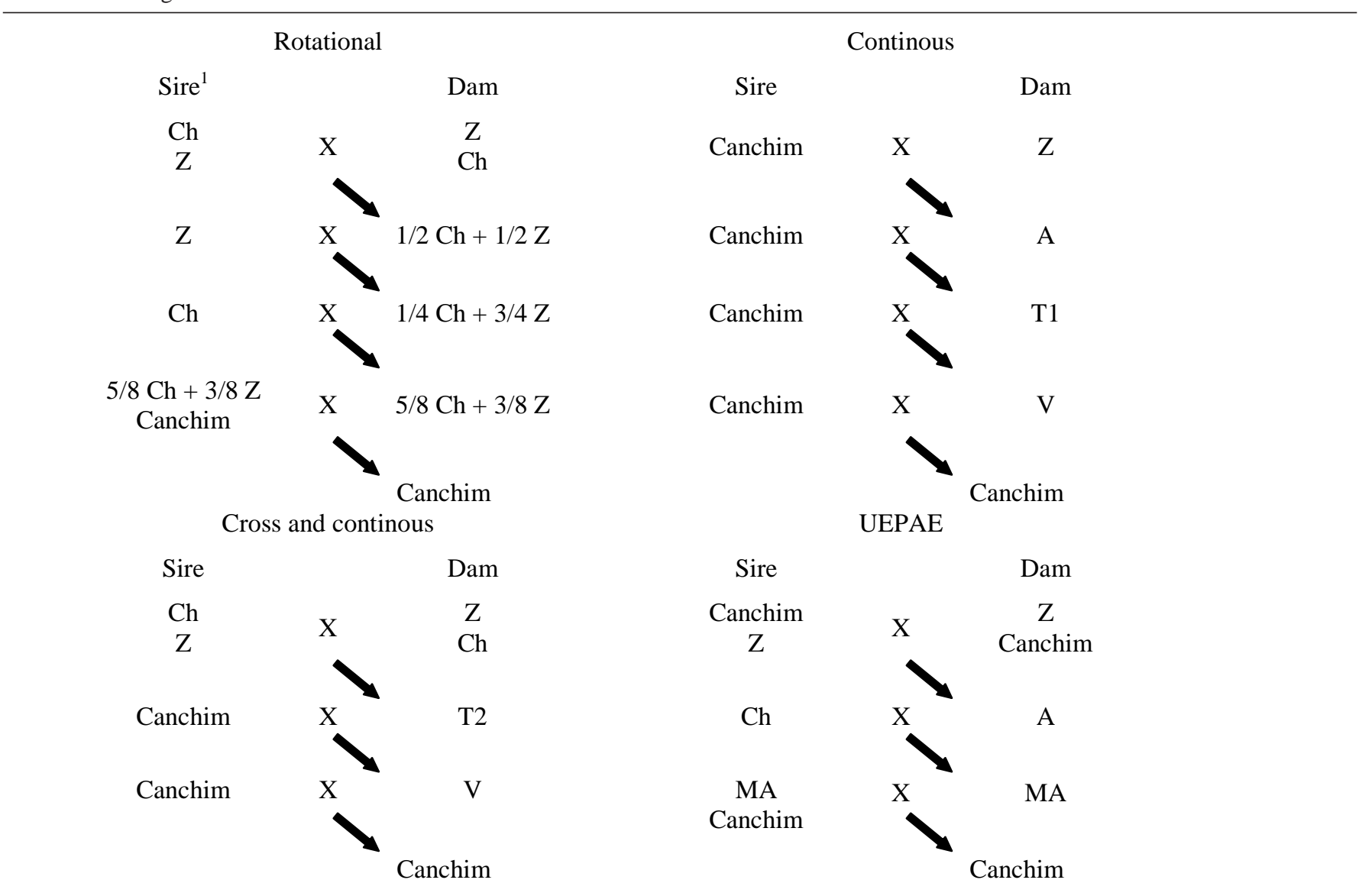

\footnotetext{
${ }^{1} \mathrm{Ch}=$ Charolais; Z = Zebu; A = 5/16 Ch + 11/16 Z; T1 = 15/32 Ch + 17/32 Z; T2 = 1/2 Ch + 1/2 Z; V = 9/16 Ch + 7/16 Z; and MA = 21/32 Ch + 11/32 Z. Source: ABCCAN
} (2008). 
for each AOD, at the interval of 2.00-15.00 years and the mean of all the points, obtained at each 0.01 year, within this interval. The CS value can be calculated by using:

$$
C S_{m(t)}=W \hat{2} 25_{m(t)}-\frac{\sum_{m=2.00}^{15.00} W \hat{2} 25_{m(t)}}{n p},
$$

where: $C S_{m(t)}=$ the value of the CS obtained for the point $m(m=2.00,2.01,2.02, \ldots, 15.00)$, for each model $t$ ( $t=$ CLA, FChFH, FCh, FH and NINT); $W 225_{m(t)}=$ the estimate of W225 at point $m$ estimated with the model $t$; and $n p=$ the number of points in the $2.00-15.00$ year interval $(n p=1,301)$. Graphs of the CS variable in a function of AOD were constructed to analyze the form of the effect of the AOD on W225 and differences in the adjustment of the models.

\section{Results and Discussion}

A lack of records was observed for animals in the first crossings used to form the Canchim breed as, for example, Charolais sire $\times$ Zebu dam and Canchim sire $\times$ Zebu dam, and of purebred Charolais and Zebu animals (Table 2).

The lack of mating of individuals with the same genetic composition and some crosses (F2, for example) occurred because in this commercial population, the crossings were aimed to produce animals with a predetermined genetic composition ( $5 / 8 \mathrm{Ch}+3 / 8 \mathrm{Z})$.

From the total observations used, $57 \%$ were derived from Canchim $\times$ Canchim mating, 19\% Charolais sire with 5/16 Ch dam and the others were distributed in 12 combinations (Table 2). From the total of calving dams, approximately $57 \%$ were younger than six years of age (Figure 1).

A reduction in the number of observations as the age of dam at increased calving was also observed (Figure 1). This fact was expected for beef cattle datasets, because the less productive dams, which were usually the older ones, are discarded after weaning the calves. Furthermore, there were few data for some genetic groups, as it was the case of the male offspring of $\mathrm{T} 1$ and $\mathrm{T} 2$ dams.

It was chosen to maintain the male offspring data of $\mathrm{T} 1$ and $\mathrm{T} 2$ dams (24 observations) in the analyzed file because these data may have been relevant to estimate the solutions of some contemporary groups. Naturally, these data were less important to estimate the solutions of the genetic groups of T1 and T2 dams, because they represented less than $2 \%$ of the total observations available for these groups. Therefore, the solutions for the $\mathrm{T} 1$ and $\mathrm{T} 2$ dam genetic groups will be confounded with the sex of the calf effect.

The inclusion of the interaction age of dam at calving $\times$ FH did not provide a better fit of the model when this was added to the simplest model $(\mathrm{FH} \times \mathrm{NINT}, \mathrm{P}=0.15)$, or when it was added to the model that already contains the age of dams at calving $\times$ FCh interaction $(\mathrm{FChFH} \times \mathrm{FCh}, \mathrm{P}=0.09$, Table 3).

The means of the absolute values of the differences in the curve shape obtained by the model that contemplates the age of dams at calving interactions with $\mathrm{FCh}$ and $\mathrm{FH}$ (FChFH) and by the model that contemplates only age of dams at calving $\times \mathrm{FCh}$, for the dams $1 / 4 \mathrm{Ch}, 5 / 16 \mathrm{Ch}$, 15/32 Ch, 1/2 Ch, 9/16 Ch, 5/8 Ch (Ch $\times 1 / 4$ Ch), 5/8 Ch $(5 / 8 \mathrm{Ch} \times 5 / 8 \mathrm{Ch})$ and 21/32 Ch, were $1.79 \mathrm{~kg}, 2.07 \mathrm{~kg}$, $0.59 \mathrm{~kg}, 3.08 \mathrm{~kg}, 0.32 \mathrm{~kg}, 0.80 \mathrm{~kg}, 0.91 \mathrm{~kg}$ and $0.32 \mathrm{~kg}$ (females) and $1.53 \mathrm{~kg}, 2.31 \mathrm{~kg}, 0.55 \mathrm{~kg}, 5.53 \mathrm{~kg}, 0.54 \mathrm{~kg}$, $2.16 \mathrm{~kg}, 1.23 \mathrm{~kg}$ and $1.33 \mathrm{~kg}$ (males), respectively (Figure 2). The greatest differences in the curve shape of the models with and without the inclusion of the age of dam at calving $\times$ FH interaction (FChFH and FCh models, respectively) were observed for the $1 / 2 \mathrm{Ch}$ group.

Considering the curve shape values of the calves from $1 / 2$ Ch dams over the age of dam at assessed calving interval, the differences were greater for age of dam at calving older than 12 years (Figure 2). This result was also

Table 2 - Number of observations of weaning weight of crossbred Charolais-Zebu calves, according to the dam and sire genetic group

\begin{tabular}{|c|c|c|c|c|c|c|}
\hline \multirow[b]{2}{*}{ Dam genetic group } & \multicolumn{6}{|c|}{ Sire genetic group } \\
\hline & Zebu & 5/8 Charolais $^{1}$ & 5/8 Charolais $^{2}$ & 21/32 Charolais & Charolais & Total \\
\hline 1/4 Charolais & & & & & 314 & 314 \\
\hline 15/32 Charolais & 7 & & 252 & & & 259 \\
\hline 1/2 Charolais & 39 & & 1,232 & & & 1,271 \\
\hline 9/16 Charolais & & & 4,973 & & & 4,973 \\
\hline 21/32 Charolais & & & 3,390 & 2,290 & & 5,680 \\
\hline Total & 66 & 297 & 43,429 & 2,290 & 10,883 & 56,965 \\
\hline
\end{tabular}

${ }^{1}$ Derived from mating of Charolais sire with $1 / 4 \mathrm{Ch}$ dam.

${ }^{2}$ Canchim, derived from mating of sire and dam $5 / 8 \mathrm{Ch}$. 
observed for the curve shape values of the calves of both sexes from 1/4 Ch and 5/16 Ch dams (Figure 2). A probable explanation for this fact is a reduction in the number of observations of dams with age at calving greater than 12 years (Figure 1), which occurs naturally in function of culling dams. Thus, both the curve shape values in the FChFH and curve shape in the FCh model were subject to greater error when fewer observations were available.

In the case of the calves from $1 / 2$ Ch dams, the differences were observed starting with age of dam at calving older than four years. It would be unwise to speculate on the reasons that caused these differences because there are practically no W225 data for male offspring from dams with hundred percent heterozygosis and the curve shape values presented in Figure 2 are extrapolations obtained from the regression coefficients estimated for the calves from dams with $\mathrm{FH}$ lower than $75 \%$.

Generally, the differences observed in the curve shape values obtained for FChFH and FH can be considered small, bearing in mind the precision of the equipment and the weighing procedures used in the field. The tendencies in the curve shape differences estimated by the FH and NINT models (data not shown) were similar to those between the FChFH and FCh models.

Cerdótes et al. (2004) reported that heterozygosis in the dam influenced its milk production. These authors observed greater production in $\mathrm{F} 1$ (Ch-N) dams compared to the purebred Nellore and Charolais dams, that did not differ from each other. It seems that the greater milk production in dams with a high percentage of heterozygosis persists throughout the productive life of the dam because in the present study significant interaction was not observed in the age of dam at calving $\times$ FH interaction on W225 and Cerdótes et al. (2004) also did not report significant effect of the age $\times$ dam genetic group interaction on milk production. In the present case, the superiority of the dam with greater FH may have been included in the solutions of the dam genetic group classificatory variable, which was included in all the statistical models assessed. These facts corroborated the suggestion for not including the age of dam at calving $\times$ FH interaction in the W225 analysis of crossbred Ch-Z calves.

The inclusions of the age of dam at calving $\times$ FCh interaction in the FH and NINT models produced significant improvements in the fit $(\mathrm{P}<0.01$, Table 3$)$, highlighting the importance of this effect to explain the variable weaning weight.

The means of the absolute values of the differences in curve shape obtained by the model that contemplated the age of dam at calving $\times$ FCh and age of dam at calving $\times \mathrm{FH}$ $(\mathrm{FChFH})$ interactions and by the model that contemplated only age of dam at calving $\times \mathrm{FH}(\mathrm{FH})$, for the dams $1 / 4 \mathrm{Ch}$, 5/16 Ch, 15/32 Ch, 1/2 Ch, 9/16 Ch, 5/8 Ch (Ch $\times 1 / 4$ Ch), 5/8 Ch (5/8 Ch $\times 5 / 8 \mathrm{Ch})$ and 21/32 Ch, were $5.00 \mathrm{~kg} ; 4.36 \mathrm{~kg}$; $1.47 \mathrm{~kg} ; 2.62 \mathrm{~kg} ; 0.26 \mathrm{~kg} ; 0.72 \mathrm{~kg} ; 1.42 \mathrm{~kg}$; and $1.32 \mathrm{~kg}$ (female) and $2.77 \mathrm{~kg} ; 0.76 \mathrm{~kg} ; 0.70 \mathrm{~kg} ; 5.44 \mathrm{~kg} ; 0.69 \mathrm{~kg} ; 3.00 \mathrm{~kg}$; $0.71 \mathrm{~kg}$; and $2.39 \mathrm{~kg}$ (males), respectively (Figure 3).

For most of the dam genetic group, not considering the effect of the age of dam at calving $\times$ FCh interaction can result in errors of fit greater than $2.5 \mathrm{~kg}$, on average, in the weight of the calves at weaning. This result reinforces the importance of the age of dam at calving $\times$ FCh interaction in a modeling of the age of dam at calving effect on W225 on crossbred Ch-Z calves.

Interactions between age of dam at calving and dam genetic group have been reported for pre-weaning characteristics in beef cattle by Massey \& Benishek (1981), Elzo et al. (1987), Gregory et al. (1991) and Alencar et al. (1999b). The differences among the weaning weights of F1 calves, offspring of Limousin sires with Angus or Hereford dams varied according to the age of dam at calving (Massey \& Benishek, 1981). Gregory et al. (1991) reported the need of using higher fit factors (for the dam age) of the weaning weight for offspring calves of Charolais dams, compared to

Table 3 - Statistics ${ }^{1}$ to compare the models for analysis of the age at calving $\times$ dam genetic group interaction on the weaning weight of Charolais-Zebu crossbred calves

\begin{tabular}{|c|c|c|c|c|c|c|c|}
\hline Model $^{2}$ & NRC & DFR & SSR & MR & $\mathrm{P}$ & EDF & $\mathrm{R}^{2}$ \\
\hline CLA & 63 & 52,433 & 37,909 & FChFH/FCh & $<0.01 /<0.01$ & $1,306.47 / 1,293.27$ & 55.69 \\
\hline FChFH & 24 & 52,472 & 37,960 & FCh/FH & $0.09 /<0.01$ & $1,228.94 / 3,176.88$ & 55.63 \\
\hline $\mathrm{FCh}$ & 16 & 52,480 & 37,969 & NINT & $<0.01$ & $3,045.09$ & 55.62 \\
\hline $\mathrm{FH}$ & 16 & 52,480 & 37,985 & NINT & 0.15 & $1,097.16$ & 55.60 \\
\hline NINT & 8 & 52,488 & 37,994 & - & & & 55.59 \\
\hline
\end{tabular}

${ }^{1}$ Number of regression coefficients (NRC), degrees of freedom of the residue (DFR), sum of squared residuals $\times 10^{-3}$ (SSR), model used as reference for the F test and the calculation of the efficiency of the additional degrees of freedom (MR), P values for the F test (P), efficiency of the additional degrees of freedom (EDF) and the coefficient of determination $\left(\mathrm{R}^{2}\right)$.

2 CLA model, estimates the AOD effect on W225 for each dam genetic group; FChFH estimates the effect of the AOD $\times$ FCh and AOD $\times$ FH interactions; FCh estimates the effect of the AOD $\times$ FCh interaction; FH estimates the AOD $\times$ FH interaction on W225 and NINT assumes that the effect of the AOD on W225 is the same for any maternal genetic group. 

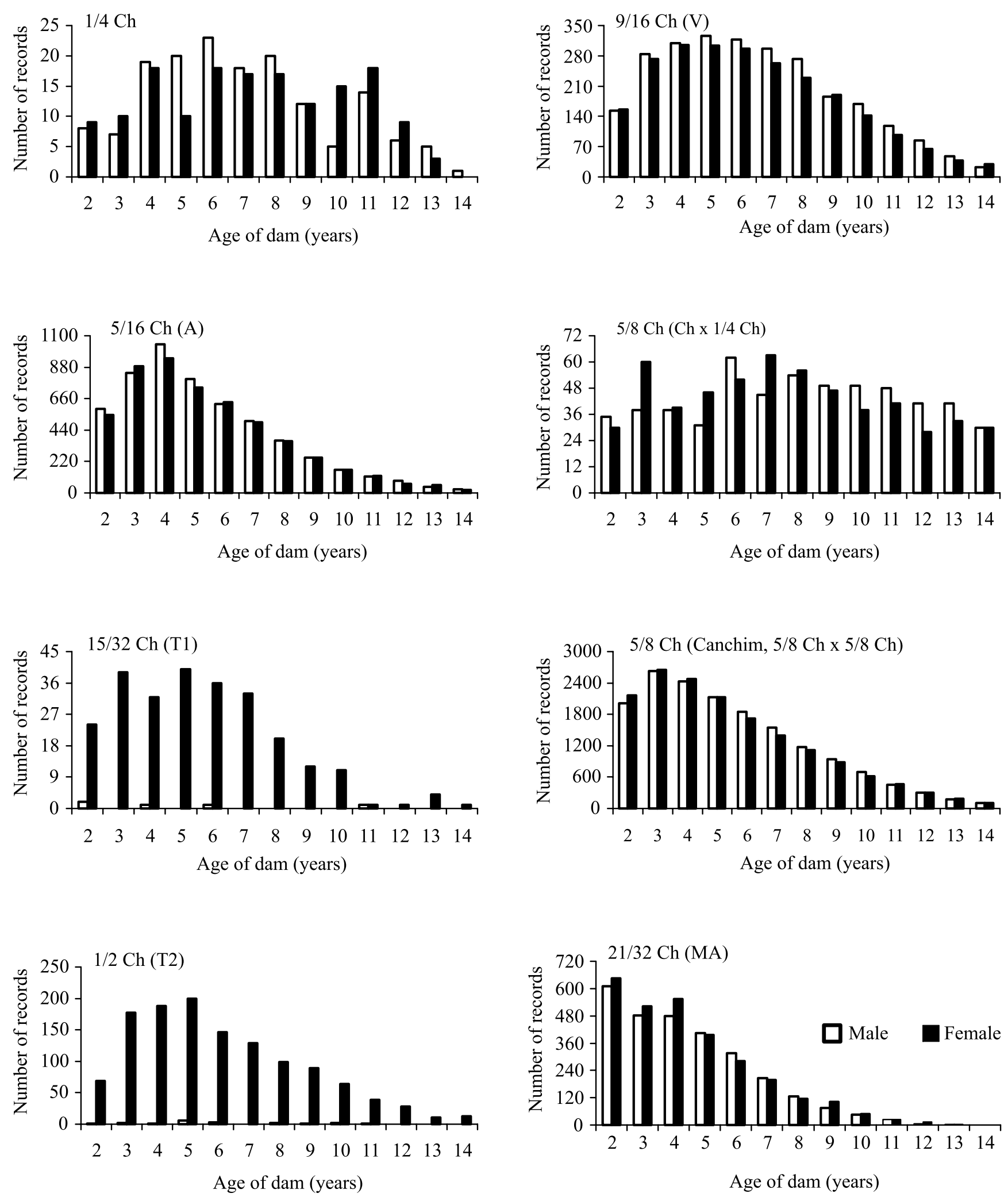

Figure 1 - Number of observations of weaning weight in the different age intervals of the dam at calving, for each dam genetic group, according to the sex of the calf. 

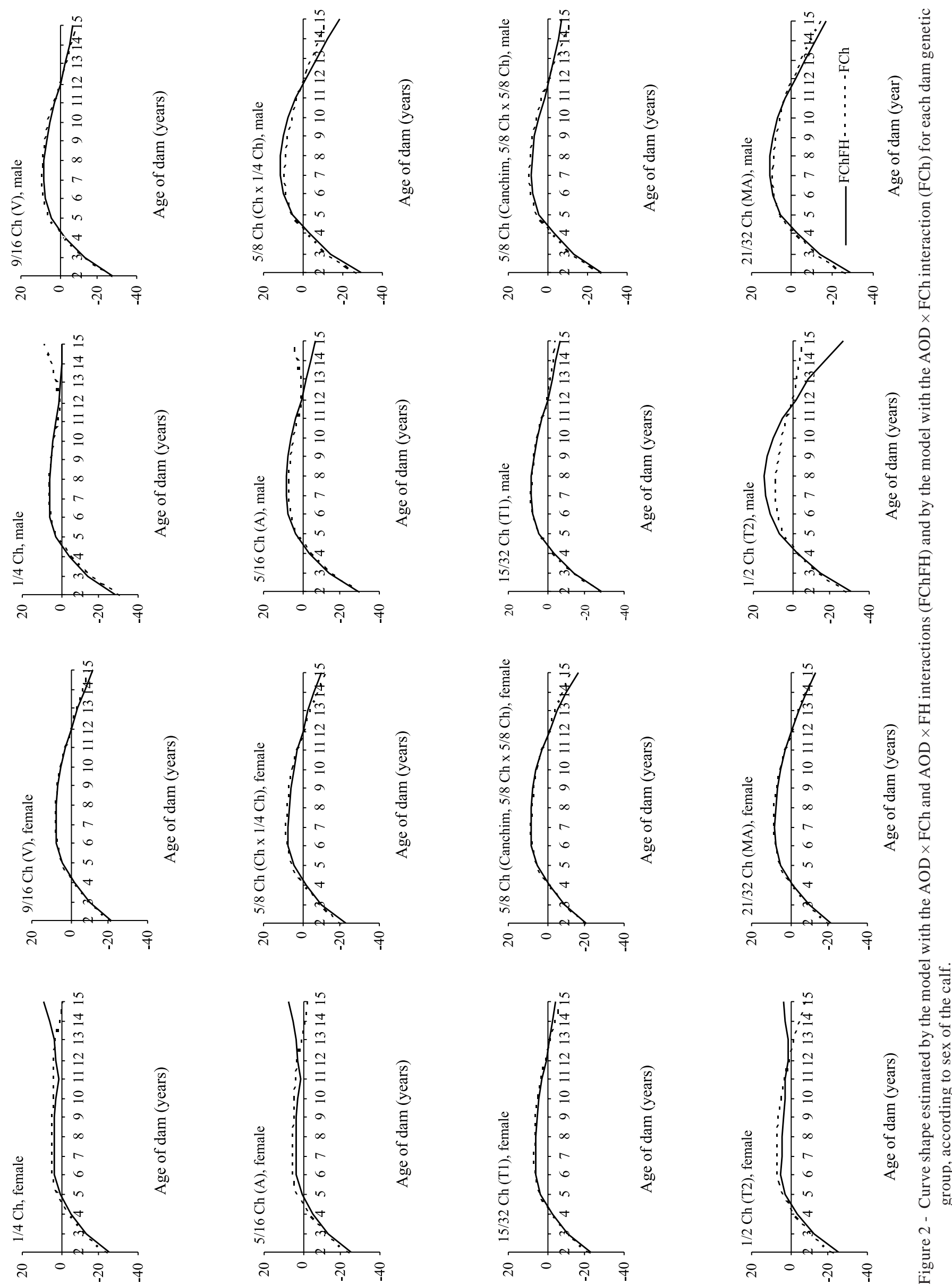

R. Bras. Zootec., v.39, n.5, p.1046-1057, 2010 


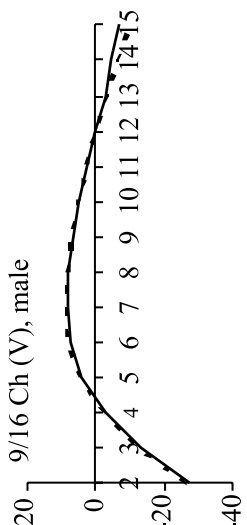

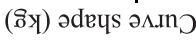

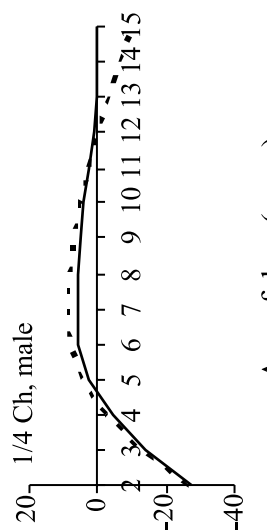

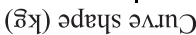

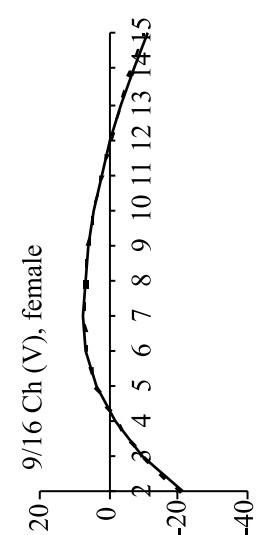

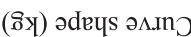

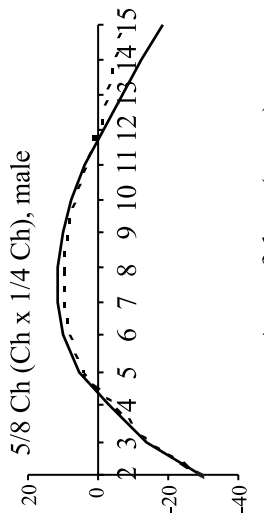

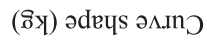

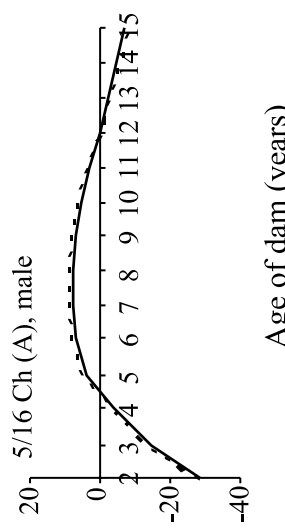

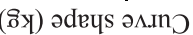

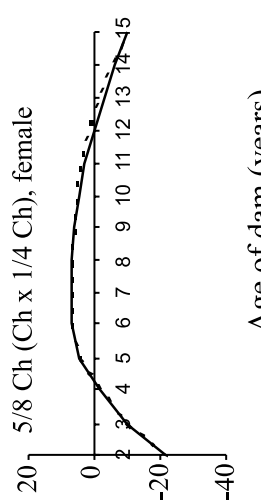

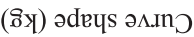

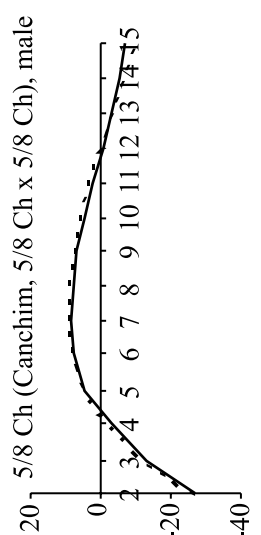

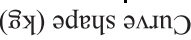

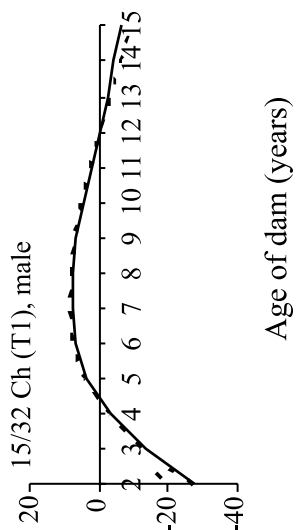

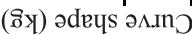

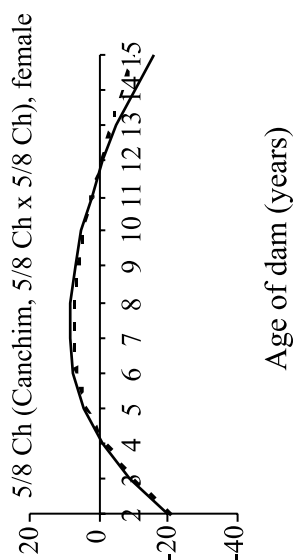

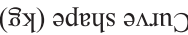

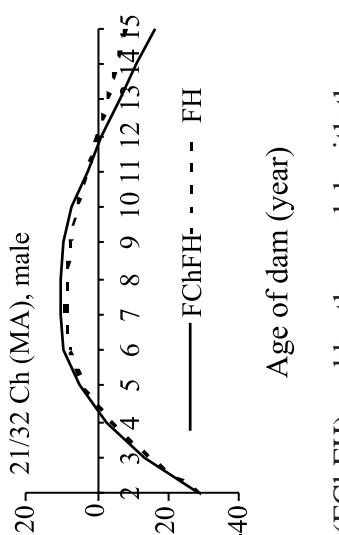

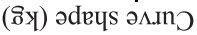

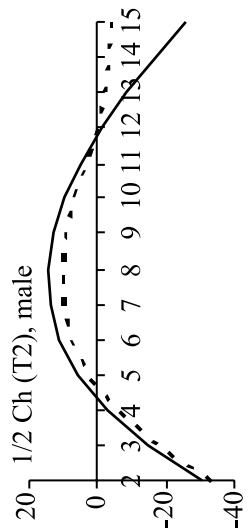

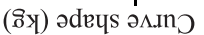

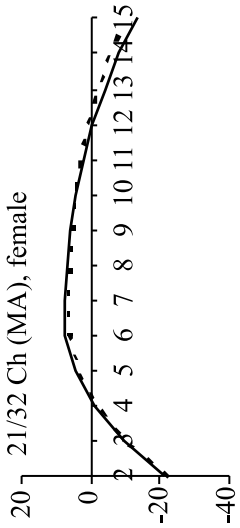

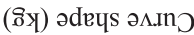

(ภิy) әdецs ә่..nว

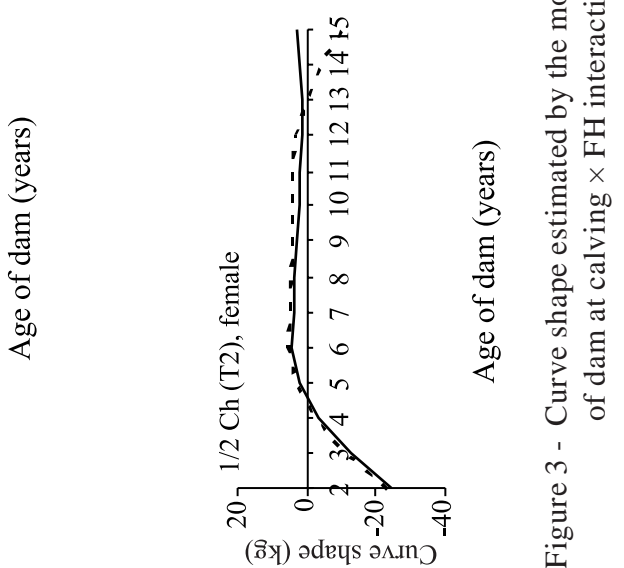

व.

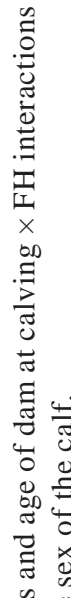
믈 을

离

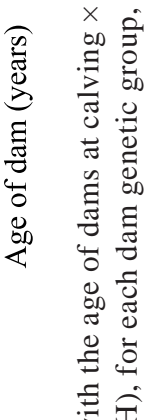

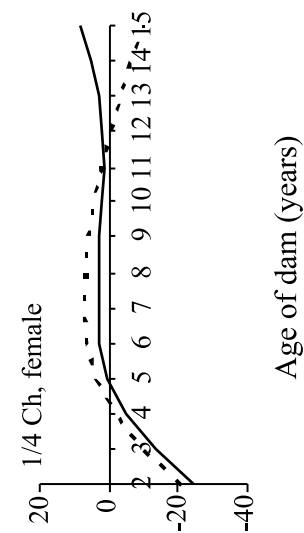

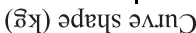

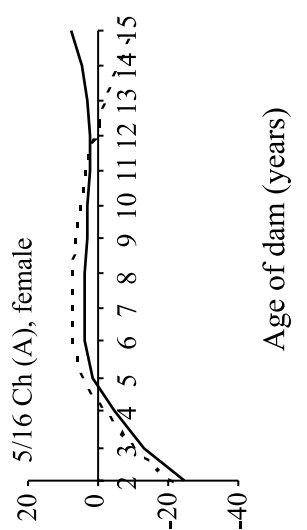

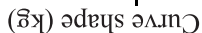

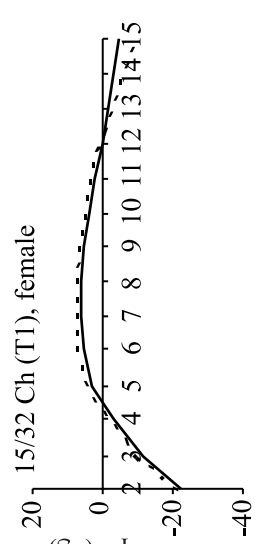

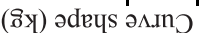

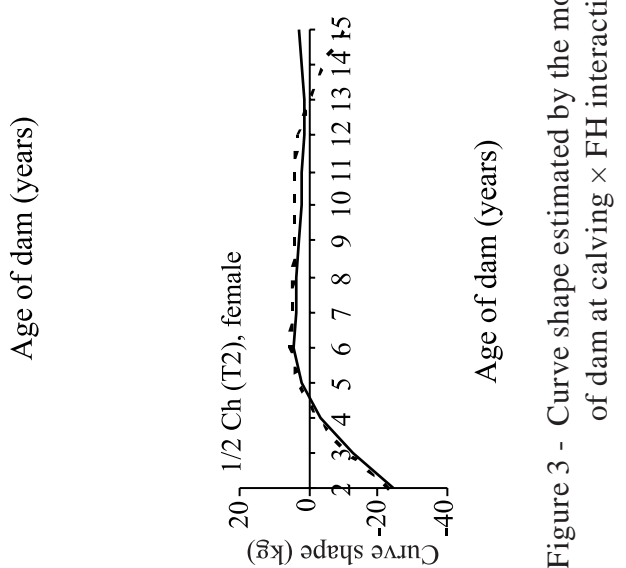

吾金 홍

R. Bras. Zootec., v.39, n.5, p.1046-1057, 2010 
the fit factors for the offspring of Angus dams. In these cases, the difference were only related to the additive genetic composition of the dam, because the maternal heterozygosis percentages were equal in the considered groups $(\mathrm{FH}=0)$.

Elzo et al. (1987) observed greater effects of age of dam at calving on the weaning weight of calves from Simmental dams than on the weight of calves from Angus or Hereford dams. The authors related the age of dam at calving $\times$ dam genetic group interaction with the differences in the maternal ability (milk production) in the compared groups, suggesting that age influenced milk production more in the dams of the Simmental breed than in the British dams. Northcutt et al. (1994) detected effect of the age of dam at calving $\times$ adult dam weight interaction on the calf weight weaning in the Angus breed. Thus, it seems that the factors adult weight and milk production are associated with the age of dam at calving $\times$ dam genetic group interaction.

The existence of different growth curves for purebred Angus (An), Brahman (Br), Charolais (Ch) and crossbred An-Br, An-Ch and Br-Ch dams (Peacock et al., 1981; Nadarajah et al., 1984) may account for a considerable part of the significant effect of the age of dam at calving $\times$ FCh interaction on W225. Peacock et al. (1981) reported greater adult weight for the Charolais dam compared to the $\mathrm{Br}-\mathrm{Ch}$ dam but did not comment on their maturation rates. Charolais dams have higher adult weights, lower maturation rates and take longer to reach the adult weight compared to the crossbred An-Ch dams (Nadarajah et al., 1984). Thus, in this longer pre-maturation phase the ingested nutrients must be used for maintenance, body growth, milk production and gestation. When these dams reach physiological maturity, they have potential to produce more milk and wean heavier calves, compared to the smaller dams, as long as their nutritional requirements are met.

The dams with a low adult weights and higher maturation rates (dams with smaller Charolais percentage) have, compared to the heavier and later dams (with greater Charolais percentage), a shorter pre-maturation period and begin to wean their heavier calves at the start of the productive life. Furthermore, as their nutritional requirements are smaller, they can be met in less intensive production systems and for longer periods of time. This may account for a lengthening of the period with weaning of heavier calves until the nutrient use efficiency begins to decrease. These effects characterize the existence of the age of dam at calving $\times$ FCh interaction, because the dams with greater FCh have greater adult weight than the dams with smaller FCh (Alencar et al., 1999a). Analysis of the curve shape performance in the dams with lower Charolais percentage $(1 / 4 \mathrm{Ch}$ and $5 / 16 \mathrm{Ch}) \times$ curve shape of the dams with higher Charolais percentage $(21 / 32 \mathrm{Ch})$ illustrated this performance (Figures 2 and 3 ).

The $\mathrm{F}$ test for the difference among the sum of squared residuals of the CLA and FCh models was statistically significant but, in this case, the EDF was less than half the EDF when the age of dam at calving $\times$ FCh interaction was added to the NINT model (Table 3), indicating that the inclusion of a further 47 degrees of freedom to the FCh model led to a less efficient parameterization.

The means of the absolute values of the differences in curve shape obtained for the CLA and FCh models, for the dams $1 / 4 \mathrm{Ch}, 5 / 16 \mathrm{Ch}, 15 / 32 \mathrm{Ch}, 1 / 2 \mathrm{Ch}, 9 / 16 \mathrm{Ch}$, 5/8 Ch $(\mathrm{Ch} \times 1 / 4 \mathrm{Ch}), 5 / 8 \mathrm{Ch}(5 / 8 \mathrm{Ch} \times 5 / 8 \mathrm{Ch})$ and 21/32 Ch, were $11.42 \mathrm{~kg}, 0.92 \mathrm{~kg}, 2.47 \mathrm{~kg}, 3.89 \mathrm{~kg}, 0.76 \mathrm{~kg}$, $3.29 \mathrm{~kg}, 0.19 \mathrm{~kg}$ and $3.76 \mathrm{~kg}$ (females) and $4.53 \mathrm{~kg}, 0.45 \mathrm{~kg}$, $127.06 \mathrm{~kg}, 448.52 \mathrm{~kg}, 2.52 \mathrm{~kg}, 3.04 \mathrm{~kg}, 0.36 \mathrm{~kg}$ and $6.86 \mathrm{~kg}$ (males), respectively (Figure 4).

Means of the absolute values of the differences in the curve shape obtained by the CLA and FCh models greater than $3 \mathrm{~kg}$ were observed for the calves of both sexes, offspring of dams $1 / 4 \mathrm{Ch}, 1 / 2 \mathrm{Ch}, 5 / 8 \mathrm{Ch}(\mathrm{Ch} \times 1 / 4 \mathrm{Ch})$ and 21/32 Ch and also for male offspring of 15/32 Ch dams.

Several factors may have contributed for obtaining striking differences in curve shape in the $1 / 2 \mathrm{Ch}$ and $5 / 8 \mathrm{Ch}$ dams $(\mathrm{Ch} \times 1 / 4 \mathrm{Ch})$. Among the dam genetic group present in the database, the $1 / 2 \mathrm{Ch}$ and 5/8 Ch were those with greatest FH (1 and 0.75, respectively). Although the age of dam at calving $\times \mathrm{FH}$ interaction was not statistically significant ( $\mathrm{P} \geq 0.09$, Table 3 ) and considering that the CLA model contemplated the age of dam at calving $\times \mathrm{FH}$ interaction, the solutions for these two groups contains the greatest part of the effect of the age of dam at calving $\times \mathrm{FH}$ interaction compared to the solutions for the groups with FH less than 0.7. Therefore, the largest expected differences in the curve shape of models with and without the age of dam calving $\times \mathrm{FH}$ interaction will be observed for these dam genetic groups.

Another concurrent fact to obtain striking differences between the curve shape in the CLA and FCh models for the $1 / 4 \mathrm{Ch}, 15 / 32 \mathrm{Ch}$ and $1 / 2 \mathrm{Ch}$ dam genetic group, especially for males (15/32 Ch and 1/2 Ch), was that few observations were available (Figure 1). Consequently, the estimated curves of the age of dams at calving effects on the W225 of males, offspring of 15/32 Ch and 1/2 Ch dams, were inconsistent and were not presented in Figure 4. Specifically for these two dam genetic group, if the CLA model had been chosen, the male data would have to be excluded because the solutions for the age of dam at calving effect would not be suitable. 

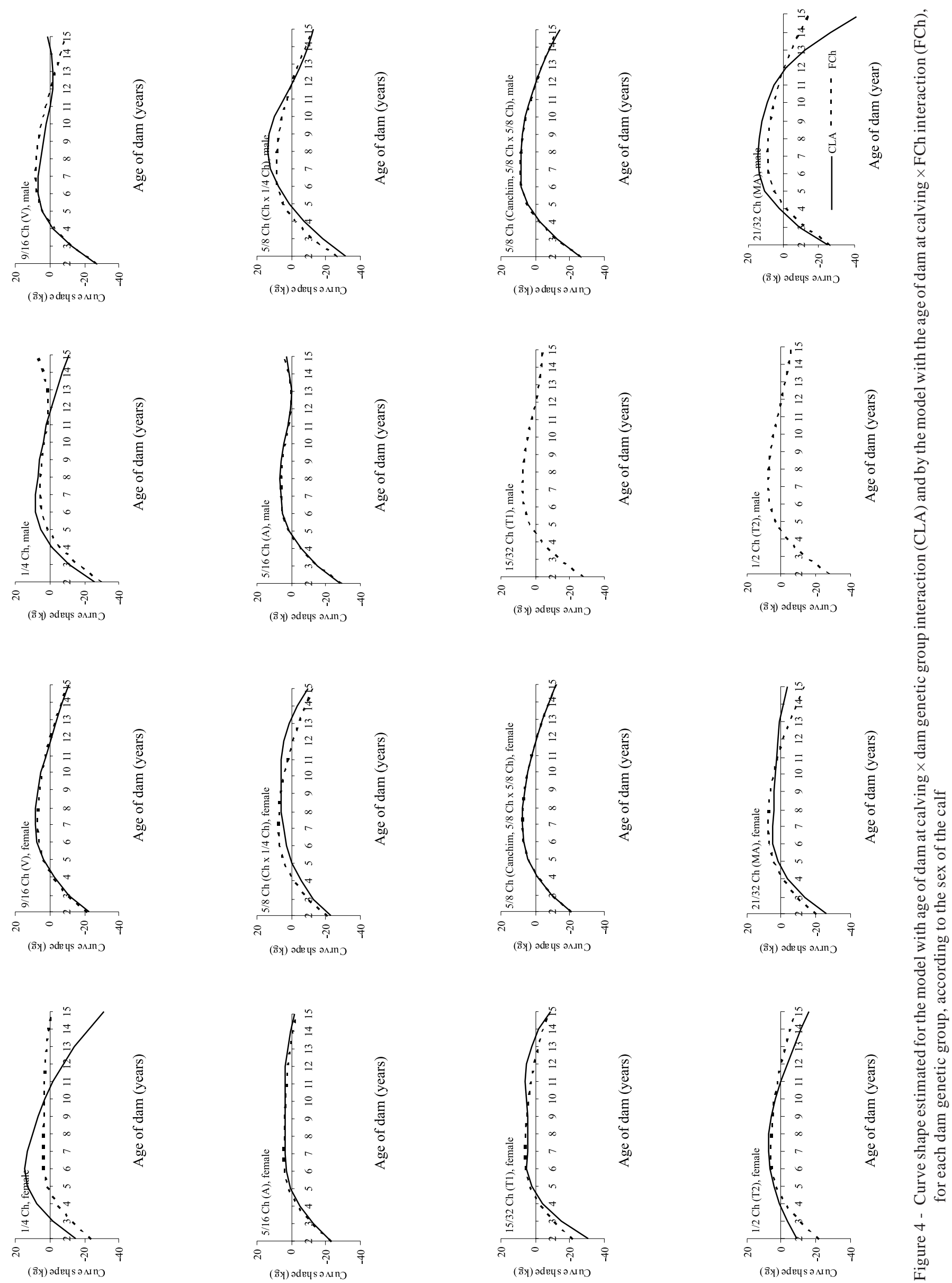
The significant reduction in the number of observations of 21/32 Ch dams over 10 years of age (Figure 1 ) may have damaged the precision of the estimates of the regression coefficient and thus led to the greater differences observed from this point.

For the age classes of dams at calving $\times$ dam genetic group $\times$ sex of the calf with fewer observations, the model containing only the age of dam at calving $\times$ FCh interaction (FCh) was shown to be more suitable than the model with the age of dam at calving effect nested in dam genetic group (CLA). In these cases, using the age of dam at calving $\times$ FCh interaction allowed the data of all the dams to be used to obtain more adequate solutions for those dam genetic group with few observations.

The smaller value obtained for EDF obtained for the CLA model compared to the FCh model (Table 3) also suggested that the parameterization of CLA was less efficient than the others. The 47 degrees of freedom of the model included in CLA, in addition to those of FCh, may represent parameters that are biologically complex and questionable. Therefore, it seems reasonable to suggest that the use of the FCh model would bring benefits to the estimates in classes with fewer observations, without causing important differences in the other situations (for example 5/8 Ch dams [Canchim, 5/8 Ch $\times 5 / 8 \mathrm{Ch}$ ], Figure 4).

The FCh model is similar to the models proposed by Klei et al. (1996), McConnel (1996) and Quaas \& Pollak (1999) to assess multi-breed genetic evaluation of animals in the American Simmental Breed Association. In the model proposed by these authors, the effect of the age of dam at calving of purebred Simmental (AODSi), Angus (AODAn) or Brahman (AODBr) dams on the calf weaning weight was estimated by regular quartic polynomials while the effects of the age of dams at calving of the crossbred dams are estimated considering the effects of the purebred dams by the genetic compositions of the crossbreds. For example, the effect of the age of dams at calving of an F1 dam (Simmental $\times$ Angus) can be estimated by $1 / 2$ AODSi + 1/2 AODAn, while the effect of the age of dam at calving of a Simbrah dam can be estimated by 5/8 AODSi + 3/8 AODBr.

By using the NINT model, it is presumed that the age of dam at calving effects are the same for all the dam genetic groups. This hypothesis could not be confirmed in the present study because the estimates of the effect of the age of dam at calving on W225 by the NINT model were different from those obtained by the other models, except for calves from Canchim dams (5/8 Ch $\times 5 / 8 \mathrm{Ch})$. This exception was justified because more than half the available data came from Canchim dams, and in this case, they would exercise greater influence on the estimates of the regression coefficients than the data from the other dam genetic group.

\section{Conclusions}

When the effect of the age at calving $\times$ dam genetic group interaction on the weaning weight is not considered in multi-breed evaluations of beef cattle, errors associated to the predictions of the genetic values in some genetic groups may increase. On the other hand, fitting the effect of the dam age at calving on the weaning weight for each sex of the calf $\times$ maternal genetic group combination may not be feasible because of the small number of observations and the inconsistent solutions obtained for some groups.

The model that contemplates the interaction of dam age at calving with its fraction of alleles derived from the Charolais breed are shown to be adequate to model the interaction of the age at calving $\times$ dam genetic composition for the classes of genetic group $\times$ sex of the calf with few observations and, for the classes with a greater number of observations, provided similar solutions to the solutions estimated with a more complete model.

\section{References}

ALENCAR, M.M.; TULLIO, R.R.; CRUZ, G.M. et al. Produção de leite da vaca e desenvolvimento do bezerro em gado de corte. Revista da Sociedade Brasileira de Zootecnia, v.25, n.1, p.92-101, 1996

ALENCAR, M.M.; OLIVEIRA, J.A.L.; ALMEIDA, M.A. Idade ao primeiro parto, peso ao parto e desempenho produtivo de vacas Nelores e cruzadas Charolês x Nelore. Revista Brasileira de Zootecnia, v.28, n.4, p.681-686, 1999a.

ALENCAR, M.M.; TULLIO, R.R.; CORRÊA, L.A. Pesos e relações de peso de bezerros filhos de vacas Nelore e cruzadas Canchim x Nelore. Revista Brasileira de Zootecnia, v.28, n.5, p.968-973, 1999b.

ASSOCIAÇÃO BRASILEIRA DE CRIADORES DE CANCHIM ABCCAN. [2008]. Novos esquemas de acasalamento para obtenção do Canchim. Disponível em: <http://www.canchim. com.br/raca.asp\#esquemas> Acesso em: 18/6/2008.

CERDÓTES, L.; RESTLE, J.; ALVES FILHO, D.C. et al. Produção e composição do leite de vacas de quarto grupos genéticos submetidas a dois manejos alimentares no período de lactação. Revista Brasileira de Zootecnia, v.33, n.3, p.610-622, 2004.

ELZO, M.A.; QUAAS, R.L.; POLLAK, E.J. Effects of age of dam on weight traits in the Simmental population. Journal of Animal Science, v.64, n.4, p.992-1001, 1987.

GREGORY, K.E.; CUNDIFF, L.V.; KOCH, R.M. Breed effects and heterosis in advanced generations of composite populations for growth traits in both sexes of beef cattle. Journal of Animal Science, v.69, n.8, p.3202-3212, 1991.

KLEI, L; QUAAS, R.L.; POLLAK, E.J. et al. Multiple breed evaluation. In: BIF ANNUAL RESEARCH SYMPOSIUM \& AnNuAl MEeting, 28., 1996, Birmingham. Proceedings... Birmingham: Beef Improvement Federation, 1996. p.93-105. 
MASSEY, M.E.; BENYSHEK, L.L. Interactions involving sires, breed of dam and age of dam for performance characteristics in Limousin cattle. Journal of Animal Science, v.53, n.4, p.940-945, 1981.

McCONNEL, M.B. Modeling age of dam effects in crossbred populations. Ithaca: Cornell University, 1996. 42f. Thesis (Bachelor's Degree with Honors) - Cornell University, 1996.

NADARAJAH, K.; MARLOWE, T.J.; NOTTER, R.D. Growth patterns of Angus, Charolais, Charolais x Angus and Holstein $x$ Angus cows from birth to maturity. Journal of Animal Science, v.59, n.4, p.957-966, 1984.

NORTHCUTT, S.L.; WILSON, D.E.; HOEKSTRA, J.A. Effect of positive genetic trend for mature size on age-of-dam adjustment factors for weaning weight in Angus field records. Journal of Animal Science, v.72, n.4, p.828-832, 1994.
PEACOCK, F.M.; KOGER, M.; OLSON, T.A. et al. Additive genetic and heterosis effects in crosses among cattle breeds of British, European and Zebu origin. Journal of Animal Science, v.52, n.5, p.1007-1013, 1981.

QUAAS, R.L.; POLLAK, E.J. Application of multi-breed genetic evaluation. In: GENETIC PREDICTION WORKSHOP, 17., 1999, Kansas City. Proceedings... Kansas City: Beef Improvement Federation, 1999. p.30-34.

TEODORO, R.L.; MARTINEZ, M.L.; VERNEQUE, R.S. et al. Parâmetros genéticos e fatores de ajuste da produção de leite para o efeito de idade da vaca ao parto na raça Guzerá. Revista Brasileira de Zootecnia, v.29, n.6, p.2248-2252, 2000 (supl.2).

TORAL, F.L.B.; TORRES JR., R.A.A.; LOPES, P.S. et al. Modeling the effect of the age of dam at calving on the weaning weight of Charolais-Zebu crossbred calves. Revista Brasileira de Zootecnia, v.38, n.7, p.1229-1237, 2009. 